\title{
A PLACE IN SOCIETY? STRENGTHENING LIVELIHOOD OPPORTUNITIES FOR STREET CHILDREN - A RIGHTS-BASED APPROACH
}

\section{John Trent, Astrid von Kotze}

\section{INTRODUCTION}

Most peoples' encounter with street children is at a robot or walking along the pavement, where they try and avoid neglected-looking young boys or girls sleeping, begging or walking unsteadily while sniffing on plastic bottles filled with cobbler's glue. We know little of their lives as our interactions are often brief and withdrawn. Whether we think of them as homeless, desperate, "victims of harsh circumstances" or a nuisance in need of care and rehabilitation, we swiftly delete their presence from our minds and move on. As Glauser (cited in Van Beers, 1996:195) suggests, "in the eyes of a large proportion of society, including policy makers and implementers, street children disrupt the tranquillity, stability and normality of society". Because of this public perception, children of the street are often convenient culprits and a target of blame for our own sense of insecurity, fear and inadequacy in a competitive world that demands ever more.

In recent years street children within the eThekwini (Durban) municipality have become more visible. This is not surprising because, according to the Proposed Policy on Children Living and Working in the Streets (PPCLWS) prepared for the eThekwini Municipality (2005:2-3), the number of children living or working on the streets in the eThekwini Municipality is estimated at above 3000. It has been suggested that Durban's warm climate acts as a draw card for children; more importantly, local economic and social factors in KZN, one of the poorest of SA provinces, and the increased pressure on poor households' limited resources mean that the most powerless members of a household, children, often feel the brunt most acutely.

Poverty is cited by many as being the main driving force behind increasing numbers of children migrating to the streets (Chetty, 1995; Hecht, 1998; Serrokh, 2006). Global and local pressures to become internationally competitive have left South Africa with increasing levels of poverty and unemployment. Moreover, abuse and other forms of oppression within the home setting and surrounding communities have further compounded the situation. The HIV/AIDS pandemic in South Africa has contributed substantially to the escalating numbers of children living on the streets and in 2002 it was predicted that by 2007416347 children in KwaZuluNatal alone would have lost at least one parent to HIV/AIDS (AIDS Orphans, 2002).

Some children become responsible for younger siblings as the head of a household and suddenly have to find a source of livelihood. Others are allocated to a family member's home where resources are already stretched beyond the capacity to feed another hungry mouth. The result may be an emergency that leads to a crisis. As a result, children are frequently abused, feel oppressed and/or unwanted and pushed out, and consequently want to escape. Some children leave their homes as a result of despair and fear; others may escape believing "that they have a better future if they move away from their situations into the land of "milk and honey", which to them means the streets of the cities" (Gopaul, 2004:94). Whatever the cause, street children become a presence in public consciousness mostly as "problems" and the response is generally removal - on the one hand, from individual compassion and conscience and, on the other hand, from the streets. The latter happens mainly in one of three ways. 
The first is through an attempt to reunite children with their families by returning them to their homes. Despite some happy-ending stories, one of the main critiques of this removal strategy is that a child is being reintegrated into a dysfunctional or abusive home environment often within a vulnerable community (Gopaul, 2004; Van Niekerk, cited in Le Roux, 2001). Secondly, this is done through placement into appropriate institutions - depending on age, shelters for homeless children or reformatories for juvenile delinquents. Again, many children do not settle well into an institutional environment and reject the rules that fly in the face of their independence and the sense of agency they have developed. As service providers have noted, "Institutions are not aiding the rehabilitation of the street child" (Bayhead Place of Safety, cited in Chetty, 1995:266). Thirdly, they are removed temporarily either into prison or "somewhere out of town", when it is deemed inappropriate for foreign visitors to witness children living on the streets of Durban. In 2004 the removal of street children for the Indaba tourism conference was highlighted by a local service provider:

We were aware of the operation, but we chose to distance ourselves because we believed the motive was wrong. I am told the kids were rounded up for the purpose of cleaning the city for the Indaba. I am told that the police rounded up the kids as though they were criminals [and that] some were dumped in far-off places out of the city (Newman, 2004:1).

More recently, in preparation for the influx of international visitors attending the 2010 soccer world-cup preliminary draw, groups of street children were again picked up and imprisoned (Daily News, 2007:1).

Representations of street children as young delinquents and dirty scoundrels reinforce the perception that street children must be rescued from themselves and the public needs to be protected from them. Disciplinary action such as corporal punishment and arrest are therefore deemed justified responses. Removal, it is argued, is in the best interest of the children because, given their child/youth and minor status, they have not yet developed the requisite rational, moral and ethical abilities that would qualify them to have a say in their lives. The claim that "adults know best what's good for children" also hides the fear that, if one were to allow children to participate in decision-making about their lives, this would place them beyond the guardianship and protection of adults and hence adults as powerful authorities lose their rights over the children. Well-meaning though it may be, this attitude places extraordinary trust in civil servants and childhood and youth specialists as moral experts whose power takes precedence over children's rights (Bessant, 2004). Continued abuse of and criminal activity against children in their own homes as much as in public institutions and spaces are sufficient evidence that the claim that "adults know best" often does not hold true (Bessant, 2004; Cockburn, 2005; Mercury, 2004). Such an attitude clearly denies children a voice and choices in their own determination and constitutes an infringement of some of the most basic human and children's rights, such as the right to liberty and security of the person, the right to adequate housing, food, clothing and the right to work. Yet removal is the response.

For a street child being taken off the street often presents being pulled out of the comfort of a household or family setting that, however inappropriate it may appear to outsiders, offers a degree of emotional and physical safety often built over time. This is borne out by an earlier study by Gopaul (2004:190), who concludes that for many children the street is home:

They portray an image of self-sufficiency and prefer to control their own lives.(...) Life is cruel and harsh on the streets and yet they leave their families at home only to make 
new ones on the street. Life at home is no better since caregivers and parents are mostly abusive.

While the best option for a child may well be to be cared for by family and community, for many children this possibility does not exist. As Thokozani, one respondent in this study, said: it would be difficult for him to return home until things were better. How could he go home if he had nothing to bring? Whether having left voluntarily or having been pushed out to fend for her/himself, there is a sense that a homecoming with dignity requires arriving with gifts and contributions. As the migrant worker father who sends remittances and returns with presents, street children see themselves as contributors to household expenses - that is, workers.

\section{THE STUDY}

Le Roux (2001:111) has asked:

Finding a way to address the street child phenomena [sic] is indeed an awkward dilemma. For many, the street is home and although life is harsh it is no worse than that from which they have come. One could consequently ask whether these children should be taught competencies and skills that will enable them to fend more adequately for themselves on the street, or should they be encouraged to reclaim their childhood?

Similarly, Aptekar and Heinonen (2003:16) have noted that:

most street children have made a conscious decision to be on the streets, whether as working, home-living children, or as working, street-living children. They have chosen, therefore, to be agents of their own destinies.

Money earned through the income-generating activities of group members gives them a certain level of freedom and independence, and in their eyes this is a preferable alternative to abusive homes and/or poverty. Aptekar and Heinonen (2003) point out that almost two decades of research and work with street children have shown that there are a number of common factors. The first is that street children regard their form of obtaining income as "work". Most defend their right to work. Secondly, the range of work that is possible on the streets is limited. There does not seem to be much variation from one city to another.

It is this self-image as workers and people who take responsibility for their own lives and living that informed the livelihood focus of this study. The research is based on work with two groups of street children in Durban in order to arrive at new insights and possible recommendations for interventions in line with a rights-based approach.

Recognising that children's experiences and insights are often radically different from our own, and that we can only begin to assist and protect children if we know what is going on in their lives from their perspective, we chose a participatory research paradigm for this study. Instead of focusing on the children as "victims of circumstance" in need of guardianship, we recognised them as subjects and agents of their daily lives and hence asked: what if they were to identify their strengths, capabilities and assets instead of deficiencies and vulnerabilities? What if they were given the opportunity to highlight some of the hazards and threats to their attempts to make a living and were then asked to outline what interventions might make a difference? In the following we briefly outline the process and tools of investigation and present the main findings. This leads to a discussion of insights generated and a set of recommendations that would support and strengthen existing activities and avert risk. 
The study drew on participatory action research (PAR) and involved young field workers employed as street educators for a local NGO. ${ }^{1}$ Throughout the study the research assistants participated in data collection and analysis, and, in the process, gained valuable, applied knowledge of both PAR tools and street children's own perceptions of their lives. The data collection tools were selected on the basis of their strengths for (a) involving the children themselves as subjects of investigation, hence foregrounding their perspective as opposed to that of outsider researchers, and (b) identifying livelihood strategies and factors that pose a risk to these strategies. "Livelihoods are defined as the activities, means and entitlements by which individuals make a living" (Lawrence, 1998:65). Here, a livelihood analysis looked at the way in which street children mobilise and allocate assets and resources at their disposal; their use of available resources to produce or exchange, or in some way earn a living; and the constraints, stresses and shocks that jeopardise such activities.

Firstly, depending on age and literacy level, participating children produced "activity clocks" to indicate the actions and activities they engage in during the course of 24 hours, through drawings accompanied by labels/text produced themselves or dictated to researchers. Secondly, they drew "mobility maps" that showed their habitat and regular movements within and outside the area of their home-places. The maps helped to locate the activities identified in the clocks geographically and pinpoint both resources drawn on daily, and hazards encountered on a regular basis, thus allowing the construction of a risk profile. The information gathered was used later in focus groups that helped to validate and extend the data, and generated discussions about how to strengthen existing livelihood activities and formulate recommendations for supporting children's endeavours to survive and increase their wellbeing.

Furthermore, observations conducted over a period of five months and reflections noted in journals kept by all researchers involved were key research tools used to triangulate all the data collected.

\section{FINDINGS}

Although the predominant focus of this study is on children of the street (those under the age of 18), there is also an awareness that children of the street co-habit with older youths within their respective street communities. Thus, although the term "children" by and large refers to those under the age of 18, the samples which were chosen are representative of a wider community, which incorporates street youths who have by-and-large lived on the street for most of their lives.

The groups that participated in the present study were composed of 37 children and youths. The Umgeni Corner group ${ }^{2}$ included 16 boys and 5 girls, who ranged in age from 11 to 25 years, while the Mayville Street group included 13 boys and 3 girls between the ages of 10 to 22 years.

Umgeni Corner is a hive of activity and the area is a mixture of residential, commercial and retail business, with a scattering of fast food outlets. The majority of residential properties in the immediate vicinity are blocks of flats in need of repair. The children live directly at a busy

\footnotetext{
${ }^{1}$ YFC (Youth for Christ) is a child and youth organisation working nationally in South Africa. Their Durban branch has specific projects focusing on homeless youths. These include primary prevention at community level, a street outreach programme and residential care for homeless girls. More information can be found at http://www.youthkzn.co.za.

${ }^{2}$ Actual sites have been re-named in order to preserve the anonymity of the group members.
} 
intersection where taxis, buses and cars pass frequently. Their only physical border is a brick wall at the back of their home and as a result they can easily be seen by traffic and passers-by alike. The group use their limited space for, amongst other things, sleeping, cooking, socialising, washing and quite often to urinate. The street corner they occupy, owned by the municipality, houses a small electricity station and is littered with a large amount of refuse.

The Mayville Street group reside in the harbour area of Durban's CBD and, again, they live and sleep next to a busy intersection. The area is predominantly made up of commercial businesses whose interests are connected to the harbour. Examples include: car terminals, custom and excise, clearing and shipping agents. There is a scattering of small retail businesses and petrol stations. Demographically the surrounding area is quite mixed, although predominantly poor, and is also renowned for drugs, prostitution and criminal activity. The group by and large have quite separate areas for sleeping, eating and socialising; however, these areas closely surround the four corners of the traffic intersection. They are less visible at night and use shrubbery running alongside the road to hide themselves from view. Their possessions are generally also less visible than the Umgeni Corner group, who utilise the space under drainage covers as storage.

\section{Constructing households}

It has been noted by a number of authors that children of the street are "quasi-families" in their respective street communities (Conticini, 2004; Swart-Kruger \& Donald, 1994). While they may not all "eat from the same pot", the groups are composed like households in which all members have distinct roles and responsibilities, and relationships are clearly defined within a hierarchical structure. Each group is headed by the older, more street-wise and experienced boys, who set rules for behaviour deemed in the best interest of young boys, and will harshly discipline the younger ones in disputes that range from money matters, to not responding to a delegated task, or access to sexual favours from a girl. Much like a patriarch would send his sons to run errands, the older boys demand "respect" from younger boys by asking them to serve and do chores for them.

The girls in the groups are "attached" to particular boys and do most of the reproductive chores such as washing and cooking for their partners. Couples care for each other: Mfana and Zanele, only 17 and 16 years old, appear to have a very deep emotional attachment and act almost like husband and wife; they are rarely seen apart from each other. In exchange for girls doing domestic tasks, boys "take care" of them, that is, protect them physically from assault and rape. Thulani spoke about:

boys who rape new girls at Umgeni Corner; those who don't have girlfriends like Lindani and others. And if your boyfriend is visiting somewhere and left you at Umgeni Corner, the boys rape you. Sometimes they are not scared of the boyfriend; they take the girl in front of the boyfriend and promise to stab you if you get in the way (HZ, journal entry, $2^{\text {nd }}$ August 2006).

\section{Daily routines}

There is regularity to daily activities that suggest routines akin to those in a "normal" household composed of poor people. The following is a description of an "aggregate" day in the life of group members. Children generally wake anytime from 6 am to $8 \mathrm{am}$. The first task is to collect water from a nearby petrol station and wash their faces. In winter the bigger boys will make a fire to keep them warm. Then some time is spent smoking cigarettes or dagga or 
sniffing glue. After this, some group members will wash clothes and hang them up to dry for the rest of the day on fencing near the road.

From about 9 am onwards some children will pursue recreational activities including swimming at the beach and going to the park, while others engage in income-generating endeavours ranging from begging, car guarding, washing cars and, on the odd occasion, a temporary job helping to load furniture onto cars and vans. These activities generally take up most of the morning until $12 \mathrm{pm}$.

The younger male members of the group go to beg at the robot intersection adjacent to their home. After they have acquired money, they use it to buy glue and maybe some food. One of the females noted going to the beach with her boyfriend, who is also a member of the group (Nosipho, activity clock, $12^{\text {th }}$ July 2006). One older male in one group described his activities as robbing people in different parts of town (Sbu, activity clock, 12 $2^{\text {th }} \mathrm{July} 2006$ ).

At any point during a typical day, events can occur which disrupt their daily activities. This often includes harassment and the data from one of the groups' activity clocks for this particular day showed a raid by the police in the early afternoon. Some of the group members were taken to the police station, but were later released.

The data collected show that afternoons are generally reserved for more recreational activities. Many of the older boys will build a fire and drink alcohol, while others sell dagga to passing traffic. Some of the children go to the park to play, while others go to meet their boyfriends/girlfriends. If they have money available, some of the girls indicated making a makeshift fire and cooking. One of the girls noted going to town to buy some stock for her small tuck shop business which she runs adjacent to their home (Thanda, activity clock $11^{\text {th }}$ July 2006). Another went to a nearby area to "sell the body" (Busi, activity clock, $12^{\text {th }}$ July 2006). Younger boys drew themselves as playing, sniffing glue and preparing for the evening shift of begging.

In the early evening begging activities for younger male members commence, while for others the evening is spent relaxing and getting high through various means. For the majority of the Umgeni Corner group, sniffing glue is a continual activity engaged in throughout the day. Both groups indicated going to sleep between $9 \mathrm{pm}$ to $10 \mathrm{pm}$, depending on the events of the day.

\section{Activities}

It became clear that, depending on their age and sex, street children engage in a mix of livelihood activities and play in the ordinary course of a day. Both the activity clocks and mobility maps showed that there are a number of strategies for satisfying basic needs for food and clothes. There were three main ways of securing food: (i) being given left-over hand-outs from passers-by, for example, at traffic lights or at restaurants; (ii) going to shelters or restaurants on particular days of the week when charity entailed food distribution; (iii) buying food with cash earned during the day. Clothes are sourced either as second-hand items offered by passengers, or donated to and distributed at shelters for street children.

Work for children of the street is always casual and often insecure. Data suggest that divisions of labour are enacted generally along the lines of sex and age. Begging is the predominant income-generating activity adopted by younger males of both sample groups, and for many younger male street children it is their only means of earning an income. In the present study children as young as 10 are begging and at such a young age are often ill-equipped to engage in alternative income-generating activities. Older street youths, who are less able to obtain income 
through activities such as begging, organise themselves into groups either to provide informal services and/or engage in criminal activity.

Young girls quickly learned the "eternal trade" of women: to sell their bodies. The findings of this study showed that girls engage regularly in sexual activities, both with their boyfriends and for cash. According to Swart-Kruger and Richter (1997:961), survival sex amongst street children is described as "sex engaged in for purposes of enlisting or mollifying powerful others, and in exchange for protection, accommodation, food, glue or other goods and services". Data showed that street children also engage in romantic relationships and this is often with a peer of similar age.

Some also run a business: Thanda from Umgeni Corner runs a small tuck-shop selling sweets and cigarettes, and Thando from Mayville Street makes some money by selling "loose" cigarettes to other children.

Older boys are engaged in more diverse income-earning activities, ranging from guarding cars to casual odd jobs such as lifting/moving furniture. Some are involved in illegal and criminal activities and in a few instances generate income through sex. Lucky's livelihood activities involved him being an "insansa", 3 as one research assistant noted:

I think Dumsani is "insansa" because in the activity clock he mentioned that the car he had drawn there was someone and him and the driver. The person in the car was his love who was taking him to their home and this person told him to bath and give him clean clothes and brush his teeth. After some time I came back to him and asked him again about the car and the people who are inside. He said it was him and he mentioned the name of a male and the driver. Then I knew that this person was a male (HZ, journal entry, $19^{\text {th }}$ July 2006).

Other group members are also aware of Lucky's work and noted when:

Dumsani was teasing Zanele, he was touching his private parts and he then touched Zanele with the same hand. Zanele replied by saying a male name which then silenced Dumsani (JT, journal entry, $19^{\text {th }}$ July 2006).

Play is an important activity of street children. Siya from Umgeni corner cited riding his bike as one of his random day activities. The younger boys often playfully wrestle and laugh and joke with one-another and any opportunity for recreational activities is gratefully received. This playfulness extended throughout the study, and during breaks in the PAR activities the researchers would play games of football with the children using found objects as make-shift balls.

Amongst all the pressures of street life, there is often the need to escape and previous research with street children in South Africa has indicated that the children's use of solvents provides a means of alleviating the stress of street living and of coping with the hazards and dangers of being a child on the streets (Swart, 1988, cited in Jansen, Richter, Griesel \& Joubert, 1989). Throughout the study it was observed that sniffing glue and smoking dagga are continual daily activities for group members from both groups, despite the fact that it is extremely detrimental to their health.

\footnotetext{
3 "Insansa" means a heterosexual male who is either forced to have homosexual sex or receives a reward for doing so.
} 
Hence, we see a "normal" mix of reproductive and productive activities that could be expected in any household, with the particular characteristics of poorer households. Livelihood activities reflect a division of labour according to age and gender, and there is a diversification of activities in order to reduce risk. Observation of both the sample groups' livelihood strategies found that children of the street are both willing and able to take on responsibility and be resourceful. For example, in preparation for the workshops the children took on the responsibility of ensuring that others would be ready to be picked up at the agreed time; in order to transport left-over food from the workshop to their home, the girls quickly sourced containers from rubbish bins. Similarly, whilst street children don't use a local clinic, they do seek medical attention when a problem is serious, and call an ambulance to take a sick member of the group to Addington Hospital on the beachfront in Durban.

Apart from just providing companionship, protection and support, the family function of street children has an apparent bearing on livelihood strategies:

One of the most valuable [functions of family relationships] is shared information regarding economic activities and safety. The former includes information about places that are best for begging, for washing cars, for getting left-over food or for soliciting. The latter includes information about unfriendly shopkeepers, dangerous locations (specific alleys, bars, etc.) and, most important, how to avoid the police (Swart-Kruger \& Donald, 1994:116).

\section{Risk assessment}

The study showed that street children are exposed to a number of daily threats and their attempts to secure a livelihood are constantly undermined as they face theft (in all forms), violence (in all forms, including rape), the threats associated with a lack of identity documents and, in the perception of the children, lesser hazards such as poor health as a result of glue sniffing, HIV infection, and nutritional deficiencies.

Respondents highlighted the fact that moving from the home space in order to go to work leaves their belongings vulnerable, and as a result not all children could work concurrently but they had to take turns guarding their space. Theft, particularly of cash earnings, from members of the groups, other children and members of the public and the police was identified as a constant threat. Sandile and Sbu were weary of particular streets as these were sites of robberies and often such attacks involved beatings. Raids by the police were described as regular occurrences and the focus groups became really lively as many of the children had stories to contribute. Nosipho said that the police chase them and on a Wednesday and Thursday they "often don't sleep because the Police come at night; they just go and hang around at a near-by area until the morning" (Focus group, $3^{\text {rd }}$ August 2006). Mfana said that "the Blackjacks know that we keep our things under the drainage covers" (Focus group, $3^{\text {rd }}$ August 2006). The "Blackjacks", that is, members of the Municipal Protection Services Unit named for their black uniforms, were described as particularly notorious by both groups, who complained that the Blackjacks take their money and possessions. On one visit to Umgeni Corner we arrived to find little evidence of the children's existence:

Lucky told me that the Blackjacks had visited them the previous evening. The Blackjacks had arrived with a van and taken all their bedding, clothes and possessions. The Blackjacks put poisonous chemicals in the pans that they use for cooking and beat some of the group members with shamboks (JT, journal entry $18^{\text {th }}$ August 2006). 
Metro Police and the Beach Police were also identified as being a danger to the children, and they developed nick-names for individuals who are particularly feared ${ }^{4}$ and warned each other about them. Risk maps showed that sometimes when group members from Mayville Street use the showers on the beachfront, the beach police hit them.

Beyond the threat of being raided and beaten by the police, it is often difficult for street children to find a safe place to sleep and bad weather may also signal assault:

Zanele explained that it was a problem when it rained as they were unable to sleep in their usual place. They would normally take shelter by one of the local businesses but if they were found there in the morning, one of the owners and manager beat them, especially the ones who cannot walk properly because of the glue (JT, journal entry, $3^{\text {rd }}$ August 2006).

Threats of assault come from others, too:

One day Thando saw people stealing cars near where they stay. When they saw that Thando had seen them, they pointed a gun at him and said that if he can tell the police about what happened in front of him, they will kill him. He was mentioning that to be on the street is a danger to him (HZ, journal entry, $19^{\text {th }}$ July 2006).

Data reflected that these cases of abuse are not only committed by outsiders, but also occur within the immediate groups of street children. This is borne out by Swart-Kruger and Richter (1997:961) who note that "Rape [is] a constant threat - by older or bigger street boys, adult men casually or part of the street scene, and in reformatories and prisons when they are apprehended by the police". Girls become victims of rape from older boys and beatings by their boyfriends if they discover that they have engaged in sexual work.

Tragically, children have no-one to turn to in order to report assault, rape or illegal arrest. In discussion groups two respondents reported that even when they seek shelter in the municipality's reception/drop-in centre, the staff might perceive them as offenders and either call the police or not intervene when a police raid leads to their arrest. Our recent observations of the police presence and harassment at the shelter were consistent with these complaints. Given their experience with police, it is no wonder that many of the children claimed it was therefore not "safe" to go to the shelter.

Older participants from both groups felt that without identity documents and education their chances of securing other forms of work are limited. As a result, they suggested that crime often remained the only alternative to make a living. Criminal activities were shown in relation to the availability of and access to jobs. Apart from the odd occasion when boys managed to secure temporary work moving furniture, data suggest that older male group members do not currently have viable work options.

Sexual activities are part the daily lives of many children living on the streets. Whether recreational or for income-generating purposes, these activities put many street children in intrinsic danger and at high risk of becoming infected with HIV. Some of the children are aware of this danger: "Busi was telling me that she just quit selling her body because it is dangerous to her because of HIV; she is positive. She is shy about what she was doing" (HZ, journal entry, $19^{\text {th }}$ July 2006).

\footnotetext{
${ }^{4}$ For example, "Goldtooth" is the name given to a particular policeman known to beat children of the street and who has an entire row of gold front teeth.
} 
Although glue was identified as a hazard in the mapping exercise, it wasn't considered a priority during the focus group discussions. During an informal interview with a research assistant, one of the children, Thando, stated that "glue is a danger to me because it makes me sick and not to walk properly" (HZ, journal entry, $19^{\text {th }}$ July 2006). Risk maps also indicated street corners and intersections as spots where the younger boys are vulnerable to having accidents, particularly when unstable on their feet because of excessive sniffing.

\section{DISCUSSION AND RECOMMENDATIONS}

Evidence from this research suggests that children of the street assume agency and attempt to "take charge" of their lives within their limited means. Street children, like adults, follow routines of livelihood activities alternating between reproductive chores, actions and "leisure". Like poor people anywhere, they diversify their activities and try to grab opportunities as they present themselves; they work in the informal economy, dependent on - and vulnerable to fickle, changing markets and events. Unlike poor adults, their choices of, and access to, income-generating activities are limited by age, size and physical capability, and they are more vulnerable to exploitation because, as children, they are considered to be worth even less than unskilled workers. Like any children (and many adults), they enjoy play, in particular organised sporting activities such as soccer. Like adults, also, recreation frequently involves substance abuse as an escape mechanism.

The problems confronting children of the street are well documented from the perspective of researchers; they include lack of shelter and associated poor hygiene and sanitation, poor diet, poor access to health care and education, sexual abuse and the associated vulnerability to sexually transmitted infections including HIV, substance abuse, including glue, dagga and alcohol (Chetty, 1995; Hecht, 1998; Swart-Kruger \& Richter, 1997). This would reflect concern for basic rights such as a decent standard of living, adequate health care and basic education. Interestingly, from the perspective of the children, harassment from the authorities, adults and other children, and, particularly for older children, the lack of identity documents as a means to access employment opportunities appeared as the main problems. This would suggest that, for them, the right to security of the person and safe and healthy working conditions are a priority.

In the following sections, we want to suggest a shift in attitude and approach consistent with our findings and a rights-based approach to working with children. Aimed at creating a space and place for them in society and not just on its fringes, this approach also draws on recent insights into child-headed households that conclude that institutional care is often unnecessary and undesirable, as children draw on extended family and/or community assistance, but require technical and financial support provided by the state or non-governmental and faith-based organisations (Bower, n.d.). Arguing against removal and for inclusion in society, we make three points: firstly, the right of children to have a say and hence be part of deliberations and decision-making that affect them; secondly, the importance of having child-friendly spaces and places where care and support can be accessed; and thirdly, the availability of work opportunities appropriate to children.

\section{Giving voice and listening}

A rights-based approach leads us to reject repeated and ongoing removal action as a first and sometimes only response. There is a need to analyse the difference between the practices of power over children by figures of authority and institutions that wield influence, and processes aimed at building power with them to define and realise mutual interests. The state, the city, 
organisations and people in positions of power should exercise this in a democratic and inclusive way that does not disempower children by reducing them to mere objects of the decisions of others, but treating them as subjects and agents who have the right to be included in decisions about their own lives. Given the opportunity, children embrace the right to participate, and this is the entry point to claiming other rights.

Building sustained relationships of trust is often a difficult task as children have no stable domicile but move in response to shifting opportunities. Furthermore, often they struggle with sustaining concentration and for some the temporary denial of toxic substances is hard to bear. Conventional and formal forms of educational interactions must be replaced by highly participatory ways that utilise visualisation and physical actions, as our interventions showed. Working for more frequent short periods rather than long ones that require sustained listening is another way of facilitating ongoing interest and engagement. Most importantly, people working with and supporting street children need to suspend assumptions and prejudices, learn to ask the right questions and listen actively. In this way we can learn from them and assist in processes of defining necessities and responsibilities. Thus, we suggest the first priority is to approach street children in the same way as we approach poor women and men: with an emphasis on their dignity and a recognition of their right to decide on their lives, in consultation with us whose role may be to counsel, to give information necessary to make informed decisions - but not to prescribe against their will.

\section{Spaces and places in the city}

Based on the information gathered with participating groups, we suggest that ways of assisting children to remain safe while on the streets must be developed. For a start, this is deemed to be a more workable option, given the large and increasing numbers of children, but such an approach is also in line with the rights of children. Hence, we concur with the Alliance, which suggests that programmes which aim to work with street children should start

working with them where they are and not trying to force them to leave the streets. In some places, authorities have introduced activities which are focused strongly on children and young people leaving the street. These are usually motivated by factors other than the best interest of the child, such as civic/political pressure to "clean up" the streets (International HIV/AIDS Alliance, n.d.).

In addition, the suggestion that children should be reunited with their families or an alternative stable family setting flies in the face of a reality in which they themselves have created family substitutes, as well as relations of care and caring. Many of the children form fairly stable relationships that are similar to extended families or households. The majority of drawings produced by the children show images of closeness: friends embracing, kissing, holding hands. Many of the narratives include references to the fact that they do not wish to live in shelters where they are not allowed to have their boy- or girlfriend with them. The experience of being loved and protected - even if this may be transitory - is also important for a child's sense of self. While not all who share a sleeping space may contribute to and eat out "of the same pot" (a definition of traditional households), members of a sleeping group establish a working relationship that is often very close, resembling the emotional ties of kinship and family. Although there is evidence that within a group there may be exploitation - particularly of young boys at the hand of older ones, and of girls in the form of sexual harassment and rape this is incidental. Compared with what the children described as the constant emotional and 
physical abuse suffered at the hands of law-enforcement officers or people they have sought to escape from by leaving home, ill-treatment by peers was regarded as insignificant.

The city belongs to all who live in it and therefore we argue strongly for the creation of childfriendly spaces. The city should be an environment where children can experience a sense of safety, recreation, beauty and care, and enjoy the services they are entitled to. Le Roux (2001:109) has observed that "life on the streets is often characterised by insecurity, violence and abuse - invariably at the hands of the very adults whom they should look up to." The whole city should be a place where children do not have to fear assault, abuse or arrest, yet instead of guaranteeing this basic right by making the city safe we, as adults, remove the children from it! What makes their fear particularly vicious is that the children seem to feel that no-one is ready to listen to them, and hence they do not trust welfare organisations and street workers to represent their interests.

Within the city the children (and in particular those who live on the street) need centrally located multipurpose drop-in centres where they can access services such as nutritious food (and nutrition education!), bathing facilities, health screening, and counselling, where they have access to information on various formal and non-formal education opportunities, living options and voluntary referral to shelters. Such drop-in centres would have to guarantee "free passage", that is, children would not run the threat of being arrested or detained. Instead, they would have to feel free to come and go, confide and be cared for, without worrying about coercion. Recognising the different interests and needs of young and older children, girls and boys, centres should have designated spaces for different age groups. Children can develop a sense of belonging and pride, if they are encouraged to participate in the design and decoration of the spaces. Such processes also offer unique opportunities for non-formal education.

Often the staff employed or working in drop-in centres consists of former street children; however, while they may draw on their experience for insight and empathy, they may also be steeped in the top-down habits so typical of adult-child relations. Child-friendly spaces need staff trained to work with children - and whose work is informed by a deep sense of social justice and the knowledge of and belief in rights - as much as in counselling and communication skills. Importantly, drop-in centres must offer opportunities for children to report misconduct, abuse and exploitation without fear of recrimination. Perpetrators from the public - ranging from men buying under-age sex, to shopkeepers selling dangerous glue, to citizens refusing to pay tips for car-guarding services - are rarely accused of complicity. However, if we want children to regain respect for adults, their rights must be seen to be respected and defended.

Drop-in centres could also be the sites where children can be given access to individually "owned" storage facilities and post-boxes. Research indicates that theft means children losing the little bit they do have, including their identity documents and cash. What if the little property they do own could be kept secure in a safe place to which only they have access? This would also allow them greater mobility to pursue livelihood activities as they could leave the sleeping place without worrying about theft. The post-boxes would further function as a means of communication between children and others, and create small spaces which they can control as "my space".

Increased and improved access to nutritious food, hygiene and sanitation would allow children to remain healthier and avert a range of skin infections and diseases; it would also allow them to clean their clothes and work on their appearance - which, in turn, would make certain casual 
work more accessible. ${ }^{5}$ Drop-in centres should offer private washing, showering and toilet facilities: this right to privacy is particularly important, considering that the children have no space they can retreat to. Regular health screening and treatment opportunities "with no strings attached" would allow children to take charge of health and infections before they become serious.

Many of the children's stories demonstrated that access to birth certificates and identity documents is recognised as crucial. Endless promises made by endless streams of researchers (as evidenced by the children) have yet to materialise such as real help with applications for identity documents. Again, drop-in centres could function as the space in which access to the Department of Home Affairs and assistance with applications is possible. This would have the additional advantage of making such centres not just safe and desirable spaces, but also useful places.

Finally, there is clear evidence that regular, formal school education suits only a minority of the children. What if the education was not based on authoritarian forms of delivery, thus conjuring memories of failure, but based on the resourcefulness and experience of the children, building on what they know rather than what they lack? What if it made them enjoy learning - as much as the participants in the PAR exercises of this research enjoyed participating and in this way found learning to be fun? In Brazil education is combined with the provision of food, and this has worked well (Swift, 1997). Similarly, if the education offered included basic skills training, thus creating potential access to income-generating activities, it might be more desirable. If drop-in centres had a truly multipurpose orientation, any of the encounters and activities would offer education and learning possibilities without having the connotations of previous school failures, shunning and the like.

\section{The right to work and make a living}

Thomas de Benitez (2003:3) has noted that:

homeless street children need to earn money or food to survive. Their work is usually sporadic, marginal, sometimes criminal and always in the informal sector. Their marginal activities put them outside the scope of any protection services geared to ensuring child labour is not exploitative or hazardous.

Although the local authorities do not support the income-generating activities of street children, the view of local NGOs and service providers is often different. In Chetty's (1997:169) study of street children in Durban, she found that $78,9 \%$ of service providers stated that street children should be provided with job opportunities and 52,1\% felt that the law should allow disadvantaged minors to work.

Money earned gives children not just a sense of independence, power and dignity, but also allows them to make choices. What if children of the street were to be given job opportunities that are appropriate to their age? If there were regular income-earning activities (such as distributing pamphlets) with a fixed minimum wage on offer and advertised by word-of-mouth, through personal post-boxes and on notice boards at drop-in centres, children would have to spend far less effort and energy looking for odd jobs and could begin to plan their livelihood activities. Viewed from the other side, the exposure might trigger a shift in employers' attitudes as they come to recognise and respect the resourcefulness of children. A regular reliable

\footnotetext{
${ }^{5}$ This is not to suggest that all children lack personal hygiene - the raggedy and dirty appearance associated with beggars is often part of the "professional outfit" that makes the appeal more compelling
} 
income would also mean that sex work was no longer the main/only livelihood activity for girls.

If children of the street were to be regarded like (other) child-headed households, this would give them a status beyond the stigmatised and criminalised status of "street children" and make them eligible for particular rights and entitlements. The Children's Bill (B70 of 2003) recognises children from the street as "children in difficult circumstances" and suggests that services to children on the street be considered in the same light as services offered to other children in need of care. If groups of street children were to be treated like other child-headed households, the state could be held accountable to ensure the provision of basic resources necessary for survival and development. This includes material support such as access to social grants, food parcels, payment of school fees, etc. Similarly, if children were to be treated like other poor households, they could expect to benefit from government responses to food insecurity that include the child support grant, food parcel campaigns and provision of maize at subsidised prices. None of these is available to street children on a reliable basis, but we would suggest rather that social development efforts would be better spent focusing on ways to construct households composed of, or including, street children. Access to child-support grant monies would free children to spend more time learning and playing, as well as participating in committees and meetings formed to deliberate and decide on their future.

\section{CONCLUSION}

While emphasising the importance of children's participation in joint efforts to constructing a better future, we also acknowledge that enlisting their sustained engagement may not be easy. Once children's experiences have led them not to trust adults and their capacity to care for them, it will take holistic, coherent and consistent efforts to re-establish this trust. Their reluctance to come forward and engage must be met with respectful communicative efforts and patience. The intoxication and hence inability of some children to function is a further limitation to participation. Reducing the dangers and hazards associated with glue sniffing is a complex issue and does not just simply involve a period of rehabilitation. If glue sniffing is used primarily as a means of staving off hunger, pain, fear and the discomfort of adverse weather, these are the causes that need to be addressed directly through the supply of food, emotional care and shelter. Drugs and glue are highly toxic and addictive escape mechanisms and the accessibility of glue makes such escape easy. Mobility maps showed where children in the two groups purchase glue (and alcohol); while there is no doubt that shopkeepers know the purpose for which a child purchases strong cobbler's glue, they sell it to them thus contributing to their habit. What if the sale of glue to children was made illegal and shopkeepers faced shame and punishment for putting greed above consideration for the health of children? Our experience suggests that fun education processes and dignified income-earning opportunities can provide enough satisfaction so that intoxication will no longer be quite as necessary.

Finally, we want to submit that measuring the success (or not) of rights-based interventions with street children would require different tools and indicators than counting the numbers of children "disappeared" from the streets. Such indicators would include, firstly, children's freedom from violence and adults' responsible participation in the daily running of street children's lives. Secondly, it would require the ability to weigh up choices and make informed decisions based on information and an understanding of their rights and a range of viable options. Thirdly, what is needed is a clear voice and say in policies formulated in consultation with those whom they are meant to serve. Fourthly, there needs to be support from community forums established to respond to the articulated needs of increasing numbers of destitute and 
homeless children. Fifthly, appropriate work opportunities and enacted regulations that protect them from exploitation or abuse are required. Sixthly, they need contact with sympathetic and open reference people and counsellors to whom they can turn in order to report attacks, and there should be clear mechanisms to redress injustices. And finally, access to small loans and banking facilities that support their efforts to create and sustain business opportunities should be made available.

Such interventions are certainly hard to establish and measure: you have to be in for "the long haul" as they require the active participation of children in their implementation. As adults we have failed our children and their insecurities are an indictment. We could respond by lending some dignity to their attempts to make a living; this research has led us to propose that this entails a more sustained way of responding to the crisis that we all have created and continue to maintain. Finally, the poignant words from Dickens's Great Expectations are a timeless reminder of how society's actions impact on children of the street: "In their little worlds in which children have their existence...there is nothing so finely perceived and so finely felt, as injustice".

\section{REFERENCES}

AIDS ORPHANS. 2002. Health Systems Trust. Available: http://www.hst.org.za/health stats/89/data. [Accessed: 12/05/2005].

APTEKAR, L. \& HEINONEN, P. 2003. Methodological implications of contextual diversity in research on street children. Children, Youth and Environments, 13(1). Available: http://www.colorado.edu/journals/cye/13_1.htm. [Accessed: 16/08/2006].

BESSANT, J. 2004. Mixed messages: youth participation and democratic practice. Australian Journal of Political Science, 39(2):387-404.

BOWER, C. n.d. South Africa: the case for child-headed households. RAPCAN. Available: http://www.rapcan.org.za/articles.htm. [Accessed: 26/02/2008].

CANADIAN INTERNATIONAL DEVELOPMENT AGENCY (CIDA). 2001. CIDA's Action Plan on Child Protection: promoting the rights of children who need special protection measures. Available: http://www.acdi-cida.gc.ca/INET/IMAGES.NSF/vLUImages/ pdf/\$file/child_protection.pdf. [Accessed: 28/02/2006].

CHETTY, V.R. 1995. A social profile of street children in the Durban Municipal area with special reference to their deviant activities. Durban: University of Durban-Westville. (Doctoral Thesis)

CHETTY, V.R. 1997. Street children in Durban: an exploratory investigation. Pretoria: HSRC Publishers.

COCKBURN, A. 2005. Who cares? Sexual abuse and street children in South Africa. Available: http://www.cyc-net.org. [Accessed: 26/02/2008].

CONTICINI, A. 2004. We are the kings: managing, protecting and promoting livelihoods on the streets of Dhaka. Institute for Development Policy and Management (IDPM), Manchester.

DAILY NEWS 22 Nov. 2007, p.1.

GOPAUL, S. 2004. The phenomenon of street children in Durban. Durban: University of Natal. (Masters Dissertation) 
HECHT, T. 1998. At home in the street. Cambridge: Cambridge University Press.

INTERNATIONAL HIV/AIDS ALLIANCE n.d. The Street. Available: http://www.ovc support.net/sw3297.asp. [Accessed: 20/11/2007].

JANSEN, P., RICHTER, L.M., GRIESEL, R.D. \& JOUBERT, J. 1989. Glue sniffing: social, psychological and neuropsychological factors in a group of South African "street children". Pretoria: UNISA.

LAWRENCE, J. 1998. Adult education and jobs, or sustainable livelihoods? In: SINGH, M. (ed) Adult learning and the changing world of work. Hamburg: UNESCO Institute for Education.

LE ROUX, C. 2001. A historical-educational perspective of urbanisation and its contribution to the street child phenomena in South Africa. EDUCARE Journal of the Faculty of Education, 30(1/2):94-114.

MERCURY 14 July 2004, p.4.

NEWMAN, L. 2004. Street children 'dumped' outside Durban. The Mercury, 18th May. Available: $\quad$ http://www.policeaccountability.co.za/CurrentInfo/ci_detail.asp?art_ID=112. [Accessed: 24/03/2005].

PROPOSED POLICY ON CHILDREN LIVING AND WORKING IN THE STREETS. 2005. The Maurice Webb Race Relations Unit, University of KwaZulu-Natal, Durban.

SERROKH, B. 2006. "Microfinance and street children". Is microfinance an appropriate tool to address the street children issue? Brussels: Free University of Brussels. (MA Dissertation)

SWART-KRUGER, J. \& DONALD, D. 1994. Children of the South African streets. In: DAWES, A. \& DONALD, D. (eds) Childhood \& adversity: psychological perspectives from South African research. Cape Town: David Philip.

SWART-KRUGER, J. \& RICHTER, L.M. 1997. AIDS-Related knowledge, attitudes and behaviour among South African street youth. Social Science and Medicine, 45(6):957-966.

SWIFT, A. 1997. Children of social change. Nottingham: Educational Heretics Press.

THOMAS DE BENITEZ, S. 2003. Reactive, protective and rights-based approaches in work with homeless street youth. Children, Youth and Environments, 13(1). Available: http://colorado.edu/journals/cye. [Accessed: 16/08/2006].

VAN BEERS, H. 1996. A plea for a child-centred approach in research with street children. Childhood, 3:195-201.

Mr John Trent \& Prof Astrid von Kotze, School of Social Work \& Community Development, University of KwaZulu-Natal, Durban, South Africa. 